\title{
Tyrosine kinase inhibitor AGI024 exerts antileukaemic effects on STI57 I-resistant Bcr-Abl expressing cells and decreases AKT phosphorylation
}

\author{
E Deutsch", , L Maggiorella', B Wen', ML Bonnet ${ }^{3}$, K Khanfir', V Frascogna', AG Turhan $^{2,3}$ and J Bourhis' \\ 'Laboratoire UPRES EA No 27-10, Radiosensibilité des tumeurs et tissus sains, Institut Gustave-Roussy, 39 rue Camille Desmoulins, 94805 Villejuif \\ Cédex, France; ${ }^{2}$ INSERM U362, Institut Gustave-Roussy, 39 rue Camille Desmoulins, 94805 Villejuif Cédex, France; ${ }^{3}$ Translational Research-Cell Therapy \\ Laboratory, Institut Gustave-Roussy, 39 rue Camille Desmoulins, 94805 Villejuif Cédex, France
}

\begin{abstract}
Chronic myelogenous leukaemia (CML) is a clonal malignancy of the pluripotent haematopoietic stem cell, characterised by an uncontrolled proliferation and expansion of myeloid progenitors expressing a fusion oncogene, BCR-ABL, the molecular counterpart of the PhI chromosome. The tyrosine kinase (TK) activity of BCR-ABL is known to activate several major signalling pathways in malignant cells, including Ras, JAK/STAT and PI3K/Akt with evidence of proteasome-mediated degradation of other targets such as the DNA repair protein DNA-PKcs and cyclin-dependent kinases inhibitor p27. Targeting these abnormalities by blocking TK of BCRABL with STI57I provided a promising approach for the therapy of CML. The recent development of resistance to STI57I illustrates, however, that the use of other TK inhibitors could be of major interest for therapeutic purposes. To this end, the TK inhibitor Tyrphostin AGI024 was used to evaluate effect on regulation of BCR-ABL expression, inhibition of cell proliferation and tumour formation in vivo in human and murine BCR-ABL expressing cell lines. Tyrphostin AGI 024 was shown to downregulate expression of BCR-ABL and P-Akt, and to upregulate DNA-PKcs expression. In addition, Tyrphostin AGI024 was able to inhibit cell proliferation, and delay tumour growth in vivo. Thus, AGI024 is able to interfere with three major targets of BCR-ABL in leukaemic cells. Interestingly, Tyrphostin AGI024 was also effective against cells resistant to STI57I by distinct mechanisms including Bcr-Abl mutation. Therefore, these data suggest that Tyrphostin AGI 024 could represent the basis of a novel therapy for STI57I refractory CML.
\end{abstract}

British Journal of Cancer (2004) 91, I735-174I. doi:I0.1038/sj.bjc.6602190 www.bjcancer.com

Published online 19 October 2004

(c) 2004 Cancer Research UK

Keywords: Bcr-Abl; Tyrphostin AGI024; AKT; IGFI; tyrosine kinase; DNA-PKcs

Chronic myelogenous leukaemia $(\mathrm{CML})$ is a myeloproliferative disorder associated with the presence of the pathognomonic Philadelphia chromosome $(\mathrm{Ph})$, which is found in approximately $95 \%$ of patients. CML is a myeloproliferative disorder and it was first described (Nowell and Hungerford, 1960) as a shortened chromosome 22 (within the Bcr locus) and a reciprocal translocation that transfers the c-abl proto-oncogene from the chromosome 9-22 (Lugo et al, 1990; McWhirter and Wang, 1991). According to the break within the Bcr locus (Quackenbush et al, 2000), three oncogenic BCR-Abl fusion proteins: p190, p210 and P230 can be formed and they all were found to be sufficient to generate leukaemia in humans and murine models (Daley et al, 1990; Huettner et al, 2000). Indeed, the Bcr-Abl oncogene was found to induce a constitutive increase in the tyrosine kinase (TK) activity (Konopka and Witte, 1985), which is sufficient for its transforming capacity. Recent advances in CML research have highlighted the role of the Bcr-Abl oncoprotein as a molecular abnormality that leads to phenotypic changes in Bcr-Abl expressing cells, and contributes to malignant transformation of cells. In fibroblasts and

*Correspondence; Dr E Deutsch; E-mail: deutsch@igr.fr

Received 25 February 2004; revised 16 August 2004; accepted 17 August 2004; published online 19 October 2004 haematopoietic cells transformation models, it was shown that Bcr-Abl induces mitogenesis (Raitano et al, 1997) and growth factor independence (Mandanas et al, 1992; Cambier et al, 1998; Issaad et al, 2000). Studies have demonstrated that the expression of $\mathrm{Bcr}-\mathrm{Abl}$ fusion proteins protects cells from apoptosis induced by stimuli such as cytokine withdrawal, DNA damage or Fas activation (Bedi et al, 1994, 1995; Benito et al, 1996). By using $\mathrm{Bcr}-\mathrm{Abl}$ mutant constructs, separated signalling pathways were found to be involved in the protection of cells from apoptosis and in cell transformation (Cortez et al, 1995). It was reported that Bcr$\mathrm{Abl}$ activates several signalling pathways including Ras, Myc, Stat5 and PI3K/Akt (14-20). The antiapoptotic potential of Bcr-Abl was attributed to the increase of $\mathrm{Bcl} 2 / \mathrm{BclXL}$ induced by the activation of Stat5 and PI3K/Akt pathways (Sanchez Garcia and Grutz, 1995; Gesbert et al, 2000). Furthermore, we previously demonstrated that DNA-PKcs (Deutsch et al, 2001) and BRCA1 (Deutsch et al, 2003), two major DNA repair proteins, are downregulated by Bcr-Abl in leukaemic cells, these downregulation processes were associated with a major DNA repair deficiency. Thus, we hypothesised that strong resistance to apoptosis along with the DNA repair deficiency induced by Bcr-Abl allow the accumulation of secondary genetic abnormalities leading to the clonal evolution toward blast crisis. 
BCR-ABL induces mitogenesis in fibroblasts and haematopoietic cells (Raitano et al, 1997). BCR-ABL expression induces growth factor independence in factor-dependent cell lines in a dosedependent manner (Issaad et al, 2000). During the recent years, progresses obtained in the understanding of the BCR-ABL-induced signalling have made possible to correlate signalling abnormalities to phenotypic changes observed in BCR-ABL-expressing cells. Previous studies using BCR-ABL mutant constructs suggested that signals responsible for protection from apoptosis may be separated from those responsible for transformation (Cortez et al, 1995). Among the major signalling intermediates activated, there is a clear role of RAS, MYC, STAT5, phosphatidylinositol 3-kinase/Akt pathways for the transforming effects of Bcr-Abl (Cleveland et al, 1989; Okuda et al, 1994; Skorski et al, 1995; Ilaria and Van Etten, 1996). The use of dominant-negative constructs allowed to determine STAT5 and PI-3K pathways to be major signalling pathways responsible of the antiapoptotic potential of BCR-ABL (Gesbert et al, 2000), by activation of Bcl2/BclXL (Sanchez Garcia and Grutz, 1995). The central role of Bcr-Abl oncogene in CML suggested $\mathrm{Bcr}-\mathrm{Abl}$ to be an attractive target for leukaemia therapy. This led to the successful development of new targeted agents such as STI571, which inhibits the TK activity of constitutive activated forms of Abl protein (v-Abl, p210Bcr-Abl, p185Bcr-Abl, Tel-Abl fusion proteins) (Buchdunger et al, 1996; Druker et al, 1996; Carroll et al, 1997). Preclinical and clinical studies have shown that Abl TK inhibition by STI571 was efficient in both p210 Bcr-Ablpositive and p185Bcr-Abl-positive cell lines as well as in primary leukaemia cells obtained from patients having Ph-positive CML and ALL (Beran et al, 1998). Further, STI571 was found to inhibit stem cell factor (SCF)-mediated cellular events such as c-Kit autophosphorylation and SCF-mediated activation of MAP kinase and Akt (Buchdunger et al, 2000; Heinrich et al, 2000). Despite the major antileukaemic effect of STI571 in chronic phase CML, clinical resistance to STI571 treatment was observed in patients with advanced phase diseases and was attributed to the mutations in the ATP-binding site of the Bcr-Abl protein, which alters drug binding and thus its inhibitory effects (La Rosee et al, 2002; RocheLestienne et al, 2002). Therefore, antileukaemic strategies targeting TK inhibition by new agents alone or in combination with STI571 need to be investigated. Bcr-Abl has been shown to be leukaemogenic in a variety of animal models (Daley et al, 1990) essentially by its deregulated TK activity (Lugo et al, 1990). PI3K and Akt have been linked to enhanced cell survival through the phosphorylation and subsequent inhibition of the proapoptotic molecule Bad (Neshat et al, 2000). Bcr-Abl regulates the expression of p27Kip1 in a proteasome-dependent manner and through activation of PI3K and Akt (Gesbert et al, 2000). Tyrphostin AG1024 has been reported to induce apoptosis and to enhance radio sensitivity by downregulating PI3K/Akt signalling pathway (Wen et al, 2001). Tyrphostin AG1024 is a TK inhibitor which inhibits phosphorylation of IGF1R and MEK and this compound is also able to induce pRb degradation (Baserga, 2000). In this study, we investigated in Bcr-Abl expressing cells the effect of this inhibitor on Akt phosphorylation and its consequences on Bcr-Abl and the DNA repair protein DNA-PKcs. Furthermore, we investigated whether Tyrphostin AG1024 induced an antileukaemic effect both in vitro and in nude mice as well as the effectiveness of Tyrphostin AG1024 against STI571 resistant cells.

\section{MATERIALS AND METHODS}

\section{Cell culture}

UT7 is a pluripotent human erythroleukaemia cell line whose growth is dependent on GM-CSF (Ahmed et al, 2000). BCR-ABLexpressing counterparts of this cell line have been obtained by the use of enforced expression of BCR-ABL by either retroviral infection or transfection as previously described (Ahmed et al, 2000). UT7-9 cells stably express high levels of the p210 fusion protein and are GM-CSF-independent for their growth. Murine $\mathrm{Ba} /$ F3 cell line and its BCR-ABL-expressing counterparts have also been previously described. Human UT7, UT7-9 and murine Ba/F3 and Ba/F3-p210 cells were grown in RPMI 1640 with $10 \%$ FCS. A measure of $10 \mathrm{ng} \mathrm{ml}^{-1}$ recombinant human granulocyte-macrophage colony-stimulated factor (rhGM-CSF) (R\&D Systems, Minneapolis, MN, USA) was added to the culture media of UT7 cells and $10 \%$ WEHI conditioned medium as a source of interleukin 3 (IL-3) was added to the culture medium of $\mathrm{Ba} / \mathrm{F} 3$ cells.

\section{Imatinib mesylate (Gleevec) resistant cells}

Cell lines CML blast-crisis K562 and the partially STI571 resistant K562R cells were kindly provided by Dr Weisberg, Dana Farber Cancer Institute, Boston, USA and cultured in DMEM medium supplemented with $10 \%$ FCS. These cell lines exhibit Bcr-Abl overexpression.

Patients derived cells Bone marrow and/or peripheral blood samples from two patients were obtained after informed consent as a protocol study sanctioned by the local institutional review board (IRB). Cells were derived from a splenectomy sample of a Bcr-Ablpositive CML-blast crisis patient, who relapsed receiving imatinib mesylate (Gleevec). Mononuclear cells were isolated and used to purify CD34 + leukaemia blasts, as previously described (Deutsch et al, 2001).

\section{Assessment of apoptosis after treatment with AG1024}

After exposure to Tyrphostin AG1024, apoptotic changes were detected using fluorescein isothiocyanate (FITC)-annexin V, which binds to phosphatidylserine exposed on the outer leaflet of apoptotic cell membranes. Propidium iodide (PI) staining was used for the discrimination between apoptotic and necrotic cells among the annexin V1 cells. Cells were washed and resuspended in $490 \mathrm{ml}$ binding buffer solution (Annexin V-FITC Kit, Immunotech, Fullerton, CA, USA). Annexin V-FITC ( $5 \mathrm{ml})$ and $5 \mathrm{ml}$ PI were then added to the cell suspension for $10 \mathrm{~min}$ followed by FACS analysis.

\section{Western blot}

Cells were washed with cold PBS, and lysed in lysis buffer $(50 \mathrm{~mm}$ HEPES pH 7.4, $15 \mathrm{~mm} \mathrm{NaCl}, 0.1 \%$ Tween-20, 10\% Glycerol, $2.5 \mathrm{~mm}$ EGTA, $1 \mathrm{~mm}$ EDTA, $1 \mathrm{~mm}$ phenylmethysulphonyl fluoride, and inhibitors for proteases). Protein concentration was determined by using Bradford assay. Equal amounts of proteins were loaded into wells and separated by $5-12 \%$ SDS - PAGE gel. The proteins were transferred onto nitrocellulose membranes, blocked overnight at $4^{\circ} \mathrm{C}$ in TBS-T solution, containing $5 \%$ nonfat milk, and incubated with primary monoclonal antibodies: $\mathrm{ABL}$ (Oncogene, Cambridge, MA, USA), DNA-PKcs (Neomarker, Fremont, CA, USA), phosphoAkt (New England Biolab, Beverly, MA, USA), Akt (New England Biolab), BRCA1 (Santa Cruz Biotechnology, Santa Cruz, CA, USA). After washing, the appropriate secondary antibody conjugated to horseradish peroxydase (Jackson ImmunoResearch Lab, West Grove, PA, USA) was probed. Membranes were developed using the enhanced chemiluminescence detection system (Amersham Biotech Company, Piscataway, NJ, USA). $\beta$-Actin (Sigma) was used to control protein loading. Densitometry analysis of the relative intensity of spots has been performed in order to quantify the expression of Bcr-Abl after treatment of both K562 and K562R cells with Tyrphostin AG1024 using Mac Bas2 software.

\section{Cell proliferation assays}

To study the inhibitory effect of Tyrphostin AG1024 on cell growth, $10^{6}$ cells were plated and the different drug concentrations $(2,5,10$ 
and $50 \mathrm{~nm}$ ) were added to the medium. At the indicated time, cell number and viability were estimated by trypan blue assay.

\section{Clonogenic assays}

Both UT7 clones, K562 cells and cells derived from patients were transplanted in methylcellulose (Stem Cell Technologies) in the presence of $10 \mathrm{ng} \mathrm{ml}^{-1}$ rhGM-SCF for UT7 cells or $10 \%$ WEHI for $\mathrm{Ba} / \mathrm{F} 3$ cells and graded concentration of Tyrphostin AG1024. The surviving fraction was determined by measuring the viability of colony-forming unit compared with the corresponding untreated controls, data represent the mean of three independent experiments performed in triplicate. Colonies were estimated 10-14 days after the treatments.

\section{In vivo experiments}

Female nude mice (6-8 weeks old) were purchased from Janvier CERT 53940 Le Genest St Isle, France. Animals used in this study were maintained in facilities in accordance with current regulations and observing 'Principles and Guidelines for the Use of Animals in Research' Issued by the French government according to the European community rules. $10^{6} \mathrm{Ba} / \mathrm{F} 3$-p210 cells in $0.1 \mathrm{ml}$ of were implanted subcutaneously into the right flank of mice and the animals were randomly assigned to control or treatment group. Mice were injected i.p. with Tyrphostin AG1024 (30 $\mu \mathrm{g}$ in $100 \mu \mathrm{l})$ once per day for 2 weeks in the treatment group and with $100 \mu \mathrm{l}$ PBS in the control. The mice were inspected daily for the tumour growth and any other signs of disease or distress. The tumour volume was calculated from the greatest transverse (width) and longitudinal (length) diameter of the tumour using the formula: tumour volume $=$ length $\times$ width $^{2} / 2$.

\section{Statistical analyses}

The data are presented as mean values \pm s.e. The surface areas of the primary tumours and the body weights were compared by paired student's $t$-test.

\section{RESULTS}

\section{Downregulation of BCR-ABL expression by Tyrphostin AG1024}

Immunoblot analysis was used to assess the expression of the fusion protein Bcr-abl in UT7-9 and Ba/F3-p210 cells after treatment with Tyrphostin AG1024. As shown in Figure 1,
A

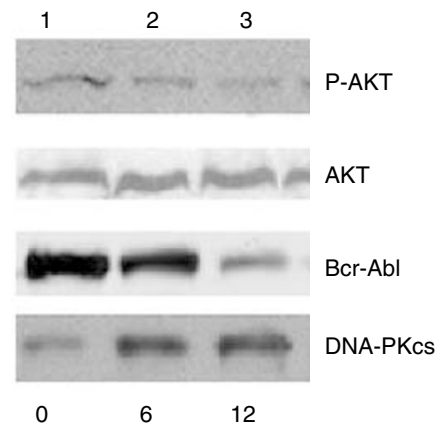

B

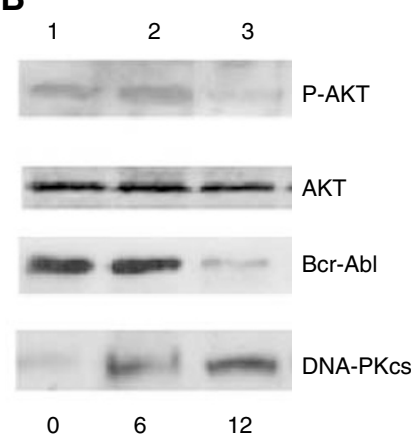

Figure I Tyrphostin AG 024 downregulates phospho-Akt, Bcr-Abl and upregulates DNA-PKcs. (A) UT7-9 and (B) Ba/F3-p2I 0 cells were treated with Tyrphostin AG $0242 \mu \mathrm{M}$, harvested at a definite time interval. Lane I: control; lane 2: $6 \mathrm{~h}$; lane 3: $12 \mathrm{~h}$. expression of Bcr-Abl was downregulated by Tyrphostin AG1024 in UT7-9 and Ba/F3-p210 cells.

\section{Tyrphostin AG1024 decreases the expression of Phospho- Akt (ser473) in BCR-ABL-expressing cells}

Further experiments were designed to measure the expression of phosphorylated forms of AKT. As shown in Figure 1, phospho-Akt (ser473) levels were downregulated by Tyrphostin AG1024, in a time-responsive manner but the amount of Akt remained the same in UT7-9 and Ba/F3-p210 cells. The expression of phospho-Akt was not influenced by the exposure to Tyrphostin AG1024 in their parental cells UT7 and Ba/F3-P (data not shown).

\section{Restoration of the DNA-PKcs levels in BCR-ABL- expressing cells by Tyrphostin AG1024}

PI3K and Akt have previously reported to play essential roles in Bcr-Abl transformation, and our previous work showed that DNA-

A Clonogenic survival with AG 1024: UT7-P and UT7-9

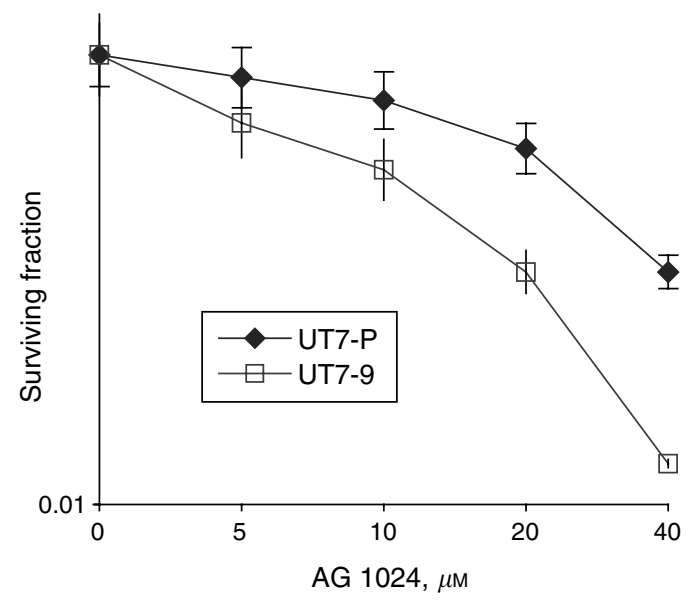

B Survival curves with AG 1024: Baf3-p210 and Baf3-P

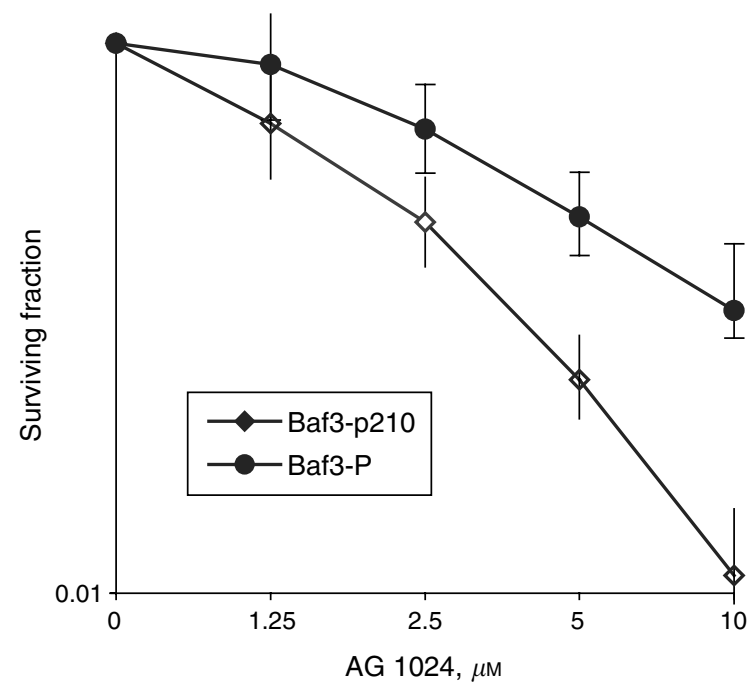

Figure 2 Clonogenic survival after exposure to Tyrphostin AGI024 of UT7 and UT7-9 cells (A), Ba/F3 and Ba/F3-p210 (B), respectively. Experiments were repeated three times, each experiment was triplicated. Error bars represent the $95 \%$ confidence interval. 
PKcs is downregulated by Bcr-Abl (23). Experiments were designed to assess whether the expression of DNA-PKcs was influenced by the TK inhibitor Tyrphostin AG1024. As shown in Figure 1, treatment with Tyrphostin AG1024 induced an upregulation of DNA-PKcs levels in UT7-9 and Ba/F3-p210 cells (Figure 1).

Decreased clonogenic survival and proliferation of murine $\mathrm{Ba} / \mathrm{F} 3$ and human UT7 BCR-ABL-expressing cell lines after exposure to Tyrphostin AG1024

Clonogenic survival assay showed that Bcr-Abl expressing cells exhibited higher colony formation inhibition than parental cells (Figure 2A and B). The effect of Tyrphostin AG1024 on cell proliferation was evaluated in UT7-9 and Ba/F3-p210 cells. Proliferation curves showed a dose-dependent inhibition of cell proliferation after treatment with Tyrphostin AG1024 (in Figure 3A). The effects of Tyrphostin on cell proliferation and clonogenic survival was associated with the induction of apoptosis (Figure 3B).

\section{In vivo inhibition of Bcr-Abl expressing cells growth with AG1024}

In order to complete, our results showing antiproliferation potential of Tyrphostin AG1024 in Bcr-Abl expressing cells in vitro. We investigated the antitumour effect of Tyrphostin AG1024 in vivo in nude mice on $\mathrm{Ba} / \mathrm{F} 3-\mathrm{p} 210$ xenografts. The tumour growth was significantly delayed when mice were treated with Tyrphostin AG1024 (Figure 4).

\section{Efficacy on Tyrphostin AG1024 on Bcr-Abl expressing STI571 resistant cells}

Proliferation curves and colony formation assays for K562 (STI571 sensitive) and K562R (STI571 resistant) cell lines were used to evaluate the effects of Tyrphostin AG1024 on cell proliferation and clonogenic survival in Bcr-Abl expressing cells resistant to STI571(Figure 5). Exposure to AG1024 caused a marked inhibition of proliferation (Figure 5) and colony formation, this effect was observed independently of the sensitivity of K562 and K562R cells to STI571. Interestingly, this effect correlates with a decrease in $\mathrm{Bcr}-\mathrm{Abl}$ protein expression in a dose-dependent manner (Figure 6). Densitometry analysis showed a reduction in Bcr-Abl expression of, respectively, 38, 43 and $61 \%$ in $\mathrm{K} 562 \mathrm{R}$ and 41,59 and $78 \%$ in cells treated with 2, 5 and $10 \mu \mathrm{M}$ Tyrphostin AG1024.

\section{CML cells from STI571 resistant patients are sensitive to Tyrphostin AG1024}

Clonogenic survival with Tyrphostin AG1024 and STI571 was studied in order to evaluate the effects of this combination on clonogenic CML cells obtained from patients relapsing after STI571 treatment. The AG1024 and STI571 were added directly to the methylcellulose cultures at the time of clonogenic assay and the results were compared to untreated controls. We observed a significant inhibition of clonogenic activity with Tyrphostin AG1024 in two different cases, primary leukaemic cells from two CML from patients clinically refractory to STI571 treatment (Figure 7) and in splenocytes derived from one CML patient refractory to STI571 (Figure 7 and Figure 8 respectively).
A

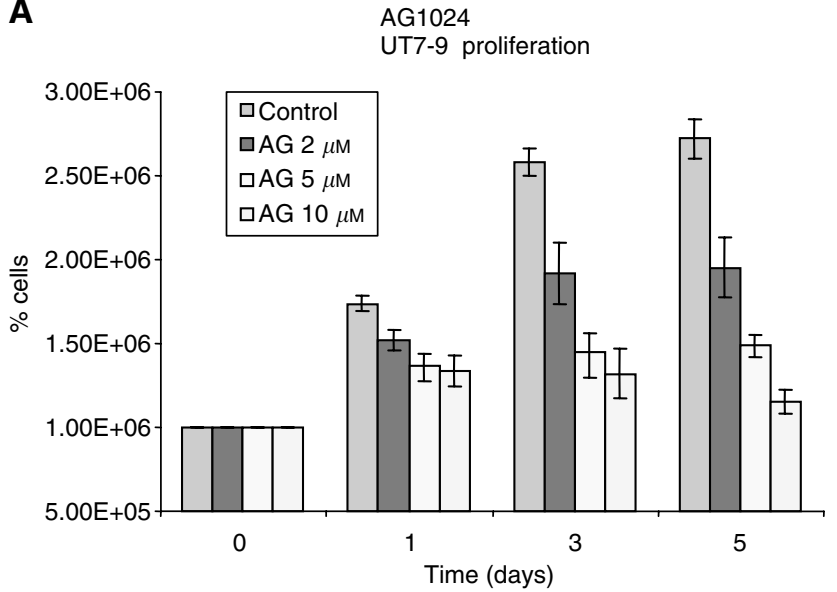

B

Apoptosis after AG1024 exposure in UT7-9 cells

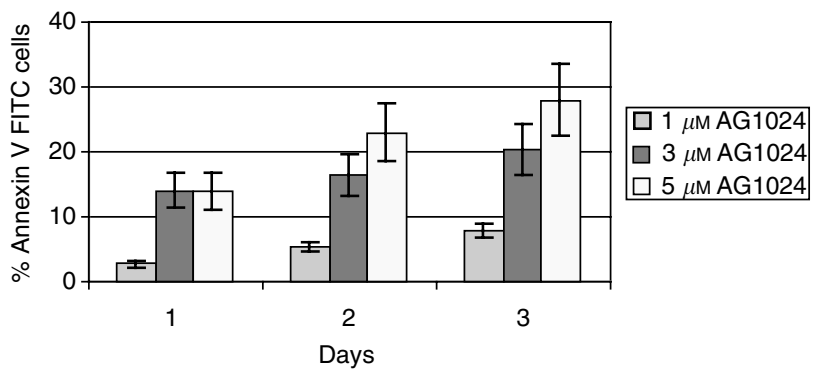

AG1024

Baf3-p210 proliferation

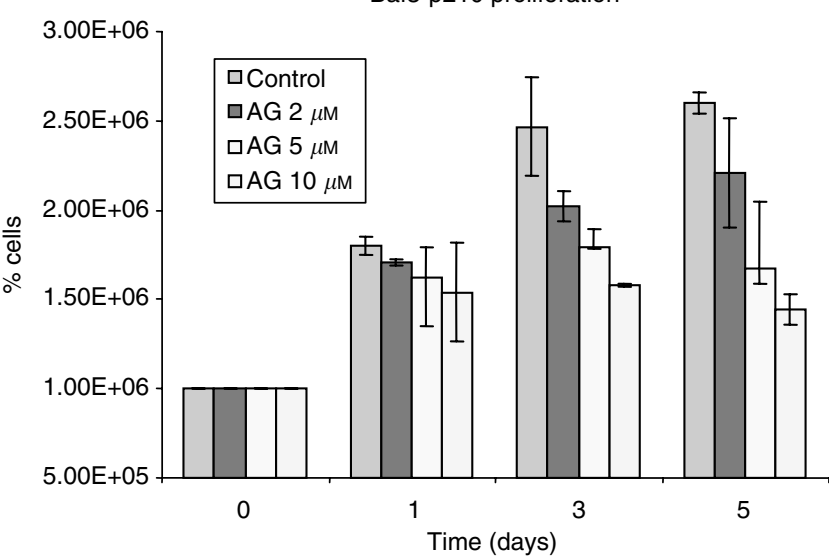

Apoptosis after AG1024 exposure in $\mathrm{Ba} / \mathrm{F} 3 \mathrm{P} 210$ cells

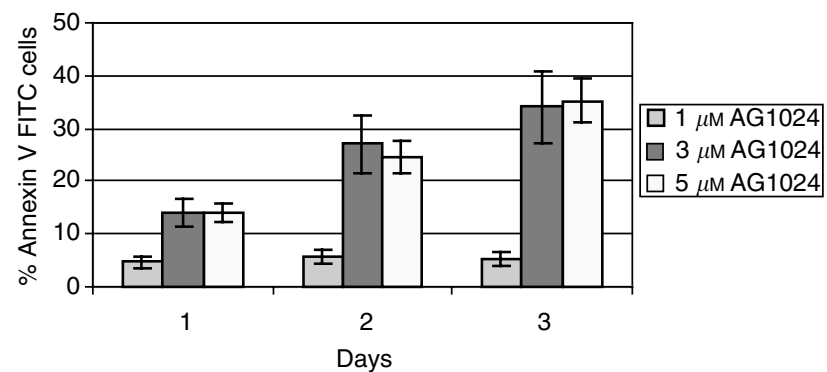

Figure 3 Antiproliferative effect of Tyrphostin AG 024 in UT7-9 and Baf3-p2 10 cells. (A) Time course of cell proliferation in different concentrations of Tyrphostin AGI024 in UT7-9 and Baf3-p2 10 cells, each experiment was carried out triplicate and repeated three times. Error bar shows the mean \pm s.e. (B) A time course of apoptosis after exposure to different concentrations of Tyrphostin AGI 024 in UT7-9 and Baf3-p2 I 0 cells, each experiment was carried out in triplicate and repeated three times. Error bar shows the mean \pm s.e. 


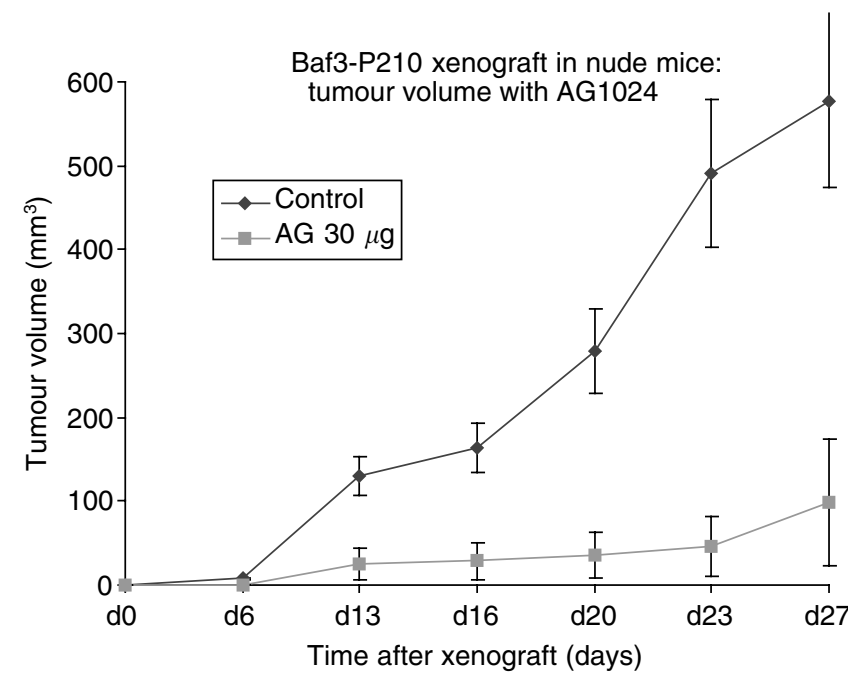

Figure 4 Antitumour effect of Tyrphostin AGI024 Ba/F3-p2I0 cells. After injection with $10^{6}$ cells $/ 0.1 \mathrm{ml}$ nude mice were injected after 6 days with PBS $0.1 \mathrm{ml}$ (control) or Tyrphostin AGI024 $30 \mu \mathrm{g} / 0.1 \mathrm{ml}(0.1 \mathrm{ml}$ of a $980 \mu \mathrm{M}$ solution) in treatment group i.p. per day for 10 days. The experiment was repeated two times with five animals in each group. Error bars represent the mean \pm s.e. of the ratio.

Interestingly, AG1024 concentration of 10 and $50 \mu \mathrm{M}$ are more effective on CML cells than on normal CD34 cells, suggesting the existence of a differential effect of Tyrphostin AG1024 (Figure 7).

\section{DISCUSSION}

Our results have shown that the proliferation of Bcr-Abl expressing cells was inhibited after Tyrphostin AG1024 treatment both in human and murine cell lines in vitro. This growth inhibitory effect was also effective in vivo, in the murine $\mathrm{Ba} / \mathrm{F} 3 \mathrm{Bcr}-\mathrm{Abl}-\mathrm{p} 210$ leukaemia xenograft model without inducing significant toxicity. Molecular studies of protein expression showed that exposure to AG1024 was associated with a decrease in the phosphorylated form of Akt (Ser 473), which is the main downstream component of the PI3K/Akt pathway responsible of apoptosis inhibition and cell proliferation. For the first time to our knowledge we show that the TK inhibitor, Tyrphostin AG1024, increases the levels of DNAPKcs levels with a concomitant decrease in the expression of Bcr$\mathrm{Abl}$, suggesting that the use of AG1024 could be beneficial for the restoration of DNA-PKcs mediated repair in CML cells. This effect was associated with a concomitant decrease in the expression of the $\mathrm{Bcr}-\mathrm{Abl}$ protein in both human and murine $\mathrm{UT7}$ and $\mathrm{Ba} / \mathrm{F} 3$ models. One of the major characteristics of $\mathrm{Ph} 1+$ cells is the presence of genetic instability, associated with the progression of the disease from the chronic to the acute phase (Deutsch et al, 2001). During the last years, intense research was investigated to understand the transformation and malignant progression of leukaemic cells. Recently, a relationship between the abnormalities of DNA repair proteins and the oncoprotein Bcr-Abl was suggested (Deutsch et al, 2001). Indeed, it was established that BCR-ABL increases the mutation frequency in haematopoietic cells by inducing a 'mutator phenotype'. Abnormalities of RAD51 protein expression have been linked to chemo resistance of CML cells (Slupianek et al, 2001; Slupianek et al, 2002). The TK dependent nature of these DNA repair abnormalities suggest that the ability to restore them by the use of therapeutic agents such as STI571 could therefore have a therapeutic impact, especially if this could lead to the retardation of the occurrence of blast crisis. The inhibitory effect of AG1024 was also observed in STI571 resistant cell lines (K562R). Exposure to AG1024 in these STI571 resistant cells was
A

K562 and K562R:

proliferation after $48 \mathrm{~h}$ exposure to AG1024

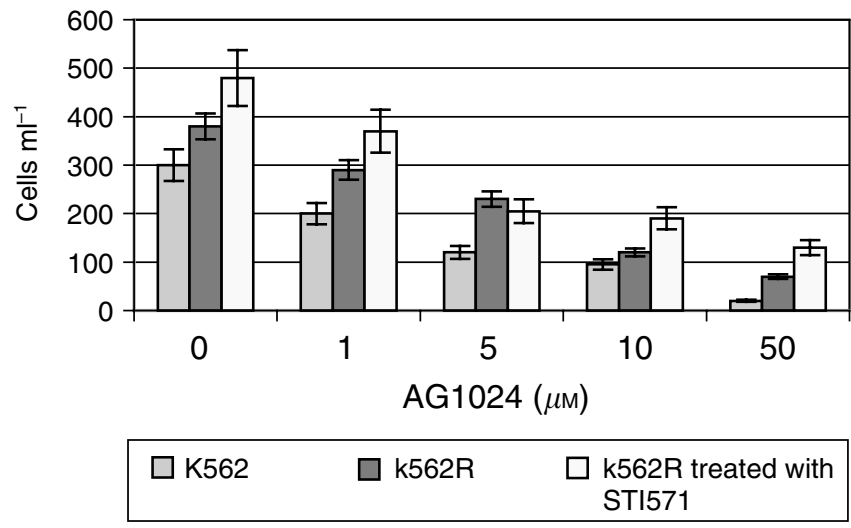

B Clonogenic survival in K562 and K562R cells with Ag1024

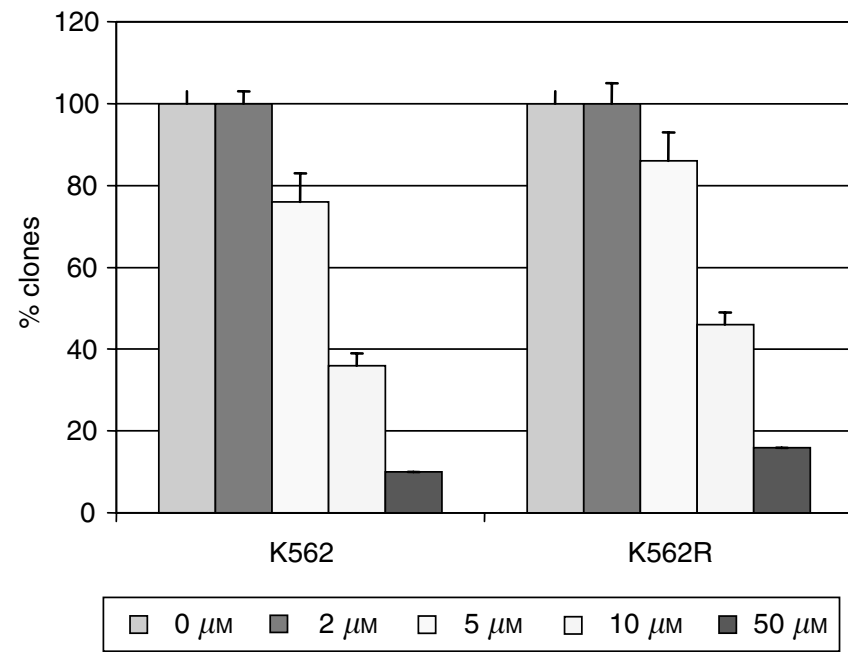

Figure 5 Effects of AGI024 exposure in the parental K562 and in the STI57I resistant K562R cell line. (A) Effects on cell proliferation after $48 \mathrm{~h}$ exposure to AGI024 on K562 and K562R cell lines. Experiments were repeated three times, each experiment was in triplicate. Error bars represent the $95 \%$ confidence interval. (B) Effects of AG I 024 on K562 and K562R colony formation after 10 days culture in a semisolid. Experiments were repeated three times, each experiment was in triplicate. Error bars represent the $95 \%$ confidence interval.

\begin{tabular}{|c|c|c|c|c|c|c|c|c|}
\hline \multirow[b]{2}{*}{ AG1024 $(\mu \mathrm{M})$} & \multicolumn{4}{|c|}{ K562R } & \multicolumn{4}{|c|}{ K562 } \\
\hline & 0 & 2 & 5 & 10 & 0 & 2 & 5 & 10 \\
\hline Bcr-Abl & 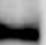 & 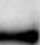 & & -4 & $=$ & $\longrightarrow$ & -4 & -4 \\
\hline
\end{tabular}

Figure 6 Western blot analysis of Bcr-Abl expression in $\mathrm{K} 562$ and K562R cells after exposure to AGI024. $\beta$-Actin was used as a loading control.

associated with a decrease in Bcr-Abl protein expression both in K562 and K562R cell lines, but this phenomenon was observed at higher Tyrphostin AG1024 concentrations than in the UT7 and Ba/ F3 cell lines. Bcr-Abl expressing cells from CML patients refractory to STI571 treated with Tyrphostin AG1024 also showed a marked decrease in clonogenic survival. Tyrphostin AG1024 is a TK 
Splenocytes from STI571 resistant splenocytes

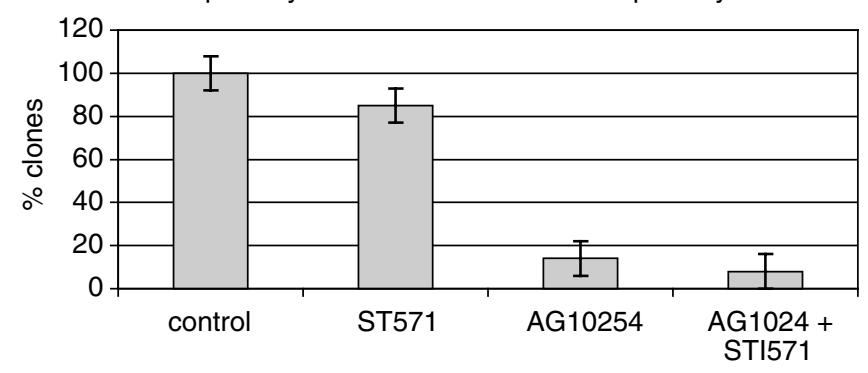

Figure 7 Effects of AG 1024 on colony formation after 10 days culture in a semisolid methylcellulose medium on splenocytes obtained from a CML$\mathrm{BC}$ patients refractory to STI57I. Cells were treated with STI57I at I $\mu \mathrm{M}$, AGI024 at $50 \mu \mathrm{M}$. Error bars represent the mean \pm s.e. of the ratio.

inhibitor that has originally been reported to be specific for the IGF1 receptor, it has recently been shown that Tyrphostin AG1024 could inhibit phosphorylation of other TK such as MEK, that is part of the MAPK signalling pathway. Moreover, exposure to Tyrphostin AG1024 is also associated to both decrease in the phosphorylated form and degradation of $\mathrm{pRb}$ (vonWillebrand et al, 1998). Recently, Typhostin AG1024 has been reported to induce apoptosis and to enhance radiosensitivity by downregulating PI3K/ Akt signal pathway (Wen et al, 2001). The relative importance of IGFR signalling during Bcr-Abl tumorigenic process still has to be studied. IGF1R is a membrane TK receptor ubiquitously expressed except on mature B cells and hepatocytes (Valentinis and Baserga, 2001). Insulin-like growth factors (IGFs) have been shown to potently stimulate cell proliferation and to inhibit cell death (Komatsu et al, 1997). Several intracellular signalling pathways have been identified that are activated in response to IGF stimulation. One of them is the phosphatidylinositol 3-kinase (PI3K) pathway. In response to IGF stimulation, activated PI3K converts phosphatidylinositol 4,5-bisphosphate to phosphatidylinositol 3,4,5-trisphosphate, which results in subsequent activation of the pleckstrin homology domain-containing serine/threonine kinases PDK1 and Akt. Oncogenes like RAS, SV40 (Sell et al, 1993), the E7 viral oncoprotein (Steller et al, 1996) as well as TK receptors EGFR, PDGFR (Coppola et al, 1994) fail to operate cellular transformation in IGF1R $-/$ - fibroblasts. Whether IGF1R seems to be required for Bcr-Abl transformation has to be studied. In conclusion, Tyrphostin AG1024 was found to downregulate the expression of Bcr-Abl and P-Akt, and to upregulate the DNA-PKcs

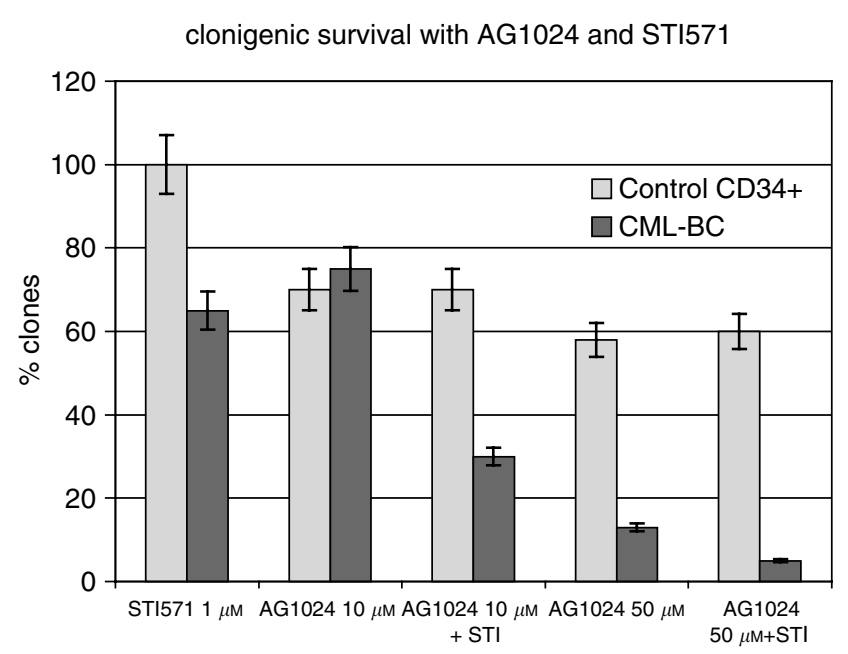

Figure 8 Effects of AG 1024 on colony formation after 10 days culture in a semisolid methylcellulose medium on cells obtained from two CML-BC patients refractory to STI57I and from control CD34 + cytapheresis cells. The percentage of clones is obtained by dividing the percentage of clones when cells are treated divided by the percentage of clones when cells are untreated. The diagram shows mean values with the two patients, each experiment was carried out in triplicate. Error bars represent the mean \pm s.e. of the ratio.

protein expression in BCR-ABL expressing cells. In vitro Tyrphostin AG1024 was found to inhibit cell proliferation and in vivo to induce tumour growth delay. In addition, an antiproliferate effect of Tyrphostin AG1024 was observed in haematopoietic cells resistant to STI571 and in primary CML cells derived from patients resistant to STI571. This effect of Tyrphostin AG1024 was observed independently of the mechanism of resistance to STI571, by Bcr$\mathrm{Abl}$ overexpression or $\mathrm{Bcr}-\mathrm{Abl}$ gene ATP pocket mutation. Therefore, this study might provide a rationale basis for a new strategy to circumvent STI571 resistance by the combined use of two distinct TK inhibitors in a curative or a preventive setting.

\section{ACKNOWLEDGEMENTS}

We are grateful to Dr Weisberg, Dana Farber Cancer Institute, Boston for providing us the K562 and K562R cell lines.

\section{REFERENCES}

Ahmed M, Dusanter-Fourt I, Bernard M, Mayeux P, Hawley RG, Bennardo T, Novault S, Bonnet ML, Gisselbrecht S, Varet B, Turhan AG (2000) BCR-ABL and constitutively active erythropoietin receptor (cEpoR) activate distinct mechanisms for growth factor-independence and inhibition of apoptosis in $\mathrm{Ba} / \mathrm{F} 3$ cell line. Oncogene 16: 489-496

Baserga R (2000) The contradictions of the insulin-like growth factor 1 receptor. Oncogene 19: 5574-5581

Bedi A, Barber JP, Bedi GC, el-Deiry WS, Sidransky D, Vala MS, Akhatar AJ, Hilton J, Jones RJ (1995) BCR-ABL-mediated inhibition of apoptosis with delay of G2/M transition after DNA damage: a mechanism of resistance to multiple anticancer agents. Blood 86: $1148-1158$

Bedi A, Zehmabauer BA, Barber JP, Sharkis SJ, Jones RJ (1994) Inhibition of apoptosis by BCR-ABL in chronic myeloid leukemia. Blood 83: 2038 2044

Benito A, Silva M, Grillot D, Nunez G, Fernandez-Luna JL (1996) Apoptosis induced by erythroid differentiation of human leukemia cell lines is inhibited by Bcl-XL. Blood 87: 3837-3843

Beran M, Cao X, Estrov Z, Jeha S, Jin G, O’Brien S, Talpaz M, Arlinghaus RB, Lydon NB, Kantarjian H (1998) Selective inhibition of cell proliferation and BCR-ABL phosphorylation in acute lymphoblastic leukemia cells expressing Mr 190000 BCR-ABL protein by a tyrosine kinase inhibitor (CGP-57148). Clin Cancer Res 7: 1661-1672

Buchdunger E, Cioffi CL, Law N, Stover D, Ohno-Jones S, Druker BJ, Lydon NB (2000) Abl protein-tyrosine kinase inhibitor STI571 inhibits in vitro signal transduction mediated by $c$-kit and platelet-derived growth factor receptors. J Pharmacol Exp Ther 1: 139-145

Buchdunger E, Zimmermann J, Mett H, Meyer T, Muller M, Druker BJ, Lydon NB (1996) Inhibition of the Abl protein-tyrosine kinase in vitro and in vivo by a 2-phenylaminopyrimidine derivative. Cancer Res 56: $100-104$

Cambier N, Chopra R, Strasser A, Metcalf D, Elefanty AG (1998) BCR-ABL activates pathways mediating cytokine independence and protection against apoptosis in murine hematopoietic cells in a dose-dependent manner. Oncogene 16: $335-348$ 
Carroll M, Ohno-Jones S, Tamura S, Buchdunger E, Zimmermann J, Lydon NB, Gilliland DG, Druker BJ (1997) CGP 57148, a tyrosine kinase inhibitor, inhibits the growth of cells expressing BCR-ABL, TEL-ABL, and TEL-PDGFR fusion proteins. Blood 12: 4947-4952

Cleveland JL, Dean M, Rosenberg N, Wang JY, Rapp UR (1989) Tyrosine kinase oncogenes abrogate interleukin-3 dependence of murine myeloid cells through signaling pathways involving c-myc: conditional regulation of c-myc transcription by temperature-sensitive v-abl. Mol Cell Biol 9: $5685-5695$

Coppola D, Ferber A, Miura M, Sell C, D’Ambrosio C, Rubin R, Baserga RA (1994) functional insulin-like growth factor I receptor is required for the mitogenic and transforming activities of the epidermal growth factor receptor. Mol Cell Biol 14: 4588-4595

Cortez D, Kadlec DL, Pendergast AM (1995) Structural and signaling requirements for Bcr-Abl-mediated transformation and inhibition of apoptosis. Mol Cell Biol 15: 5531-5541

Daley GQ, Van Etten RA, Baltimore D (1990) Induction of chronic myelogenous leukemia in mice by the $\mathrm{P} 210 \mathrm{bcr} / \mathrm{abl}$ gene of the Philadelphia chromosome. Science 247: 824-830

Deutsch E, Dugray A, AbdulKarim B, Marangoni E, Maggiorella L, Vaganay S, M'Kacher R, Rasy SD, Eschwege F, Vainchenker W, Turhan AG, Bourhis J (2001) BCR-ABL down regulates the DNA repair protein DNAPKcs. Blood 97: 2084-2090

Deutsch E, Jarrousse S, Buet D, Dugray A, Bonnet ML, Vozenin-Brotons MC, Guilhot F, Turhan AG, Feunteun J, Bourhis J (2003) Downregulation of BRCA1 in BCR-ABL-expressing hematopoietic cells. Blood 101: $4583-4588$

Druker BJ, Tamura S, Buchdunger E, Ohno S, Segal GM, Fanning S, Zimmermann J, Lydon NB (1996) Effects of a selective inhibitor of the Abl tyrosine kinase on the growth of Bcr-Abl positive cells. Nat Med 5: $561-566$

Gesbert F, Sellers WR, Signoretti S, Loda M, Griffin JD (2000) BCR/ABL regulates expression of the cyclin-dependent kinase inhibitor p27Kip1 through the phosphatidylinositol 3-Kinase/AKT pathway. J Biol Chem 275: $39223-39230$

Heinrich MC, Griffith DJ, Druker BJ, Wait CL, Ott KA, Zigler AJ (2000) Inhibition of c-kit receptor tyrosine kinase activity by STI 571, a selective tyrosine kinase inhibitor. Blood 96: 925-932

Huettner CS, Zhang P, Van Etten RA, Tenen DG (2000) Reversibility of acute B-cell leukaemia induced by BCR-ABL1. Nat Genet 24: 57-60

Ilaria Jr RL, Van Etten RA (1996) P210 and P190(BCR/ABL) induce the tyrosine phosphorylation and DNA binding activity of multiple specific STAT family members. J Biol Chem 271: 31704-31710

Issaad C, Ahmed M, Novault S, Bonnet ML, Bennardo T, Varet B, Vainchenker W, Turhan AG (2000) Biological effects induced by variable levels of BCR-ABL protein in the pluripotent hematopoietic cell line UT7. Leukemia 14: $662-670$

Komatsu N, Kirito K, Shimizu R, Kunitama M, Yamada M, Uchida M, Takatoku M, Raitano A, Whang YE, Sawyers CL (1997) Signal transduction by wild-type and leukemogenic Abl proteins. Biochim Biophys Acta 1333: $201-216$

Konopka JB, Witte ON (1985) Detection of c-abl tyrosine kinase activity in vitro permits direct comparison of normal and altered abl gene products. Mol Cell Biol 11: 3116-3123

La Rosee P, Johnson K, O'Dwyer ME, Druker BJ (2002) In vitro studies of the combination of imatinib mesylate (Gleevec) and arsenic trioxide (Trisenox) in chronic myelogenous leukemia. Exp Hematol 30: 729-737

Lugo TG, Pendergast AM, Muller AJ, Witte ON (1990) Tyrosine kinase activity and transformation potency of bcr-abl oncogene products. Science 247: 1079-1082
Mandanas RA, Boswell HS, Lu L, Leibowitz D (1992) BCR/ABL confers growth factor independence upon a murine myeloid cell line. Leukemia 6: $796-800$

McWhirter JR, Wang Jy (1991) Activation of tyrosinase kinase and microfilament-binding functions of $c$-abl by bcr sequences in bcr/abl fusion proteins. Mol Cell Biol 3: $1553-1565$

Neshat MS, Raitano AB, Wang HG, Reed JC, Sawyers CL (2000) The survival function of the Bcr-Abl oncogene is mediated by Bad-dependent and -independent pathways: roles for phosphatidylinositol 3-kinase and Raf. Mol Cell Biol 20: 1179-1186

Nowell PC, Hungerford DA (1960) A minute chromosome in human chronic granulocytic leukemia. Science 132: 1330-1340

Okuda K, Matulonis U, Salgia R, Kanakura Y, Druker B, Griffin JD (1994) Factor independence of human myeloid leukemia cell lines is associated with increased phosphorylation of the proto-oncogene Raf-1. Exp Hematol 22: $1111-1117$

Quackenbush RC, Reuther GW, Miller JP, Courtney KD, Pear WS, Pendergast AM (2000) Analysis of the biologic properties of p230 Bcr$\mathrm{Abl}$ reveals unique and overlapping properties with the oncogenic p185 and p210 Bcr-Abl tyrosine kinases. Blood 9: 2913-2921

Raitano AB, Whang YE, Sawyers CL (1997) Signal transduction by wildtype and leukemogenic Abl proteins. Biochim Biophys Acta 3: 201-216

Roche-Lestienne C, Soenen-Cornu V, Grardel-Duflos N, Lai JL, Philippe N, Facon T, Fenaux P, Preudhomme C (2002) Several types of mutations of the $\mathrm{Abl}$ gene can be found in chronic myeloid leukemia patients resistant to STI571, and they can pre-exist to the onset of treatment. Blood 100: $1014-1018$

Sanchez Garcia I, Grutz G (1995) Tumorigenic activity of the Bcr-Abl oncogene is mediated by Bcl-2. Proc Natl Acad Sci USA 92: 5287-5291

Sell C, Rubini M, Rubin R, Liu JP, Efstratiadis A, Baserga R (1993) Simian virus 40 large tumor antigen is unable to transform mouse embryonic fibroblasts lacking type 1 insulin-like growth factor receptor. Proc Natl Acad Sci USA 90: 11217-11221

Skorski T, Kanakaraj P, Neiborowska-Skorska M, Ratajczakk MZ, Wen SC, Zon G, Gerrwitz AM, Perussia P, Calabretta B (1995) phosphatidylinositol-3 kinase activity is regulated by BCR/ABL and is required for the growth of Philadelphia chromosome-positive cells. Blood 2: $726-736$

Slupianek A, Hoser G, Majsterek I, Bronisz A, Malecki M, Blasiak J, Fishel R, Skorski T (2002) Fusion tyrosine kinases induce drug resistance by stimulation of homology-dependent recombination repair, prolongation of G(2)/M phase, and protection from apoptosis. Mol Cell Biol 22: 41894201

Slupianek A, Schmutte C, Tombline G, Nieborowska-Skorska M, Hoser G, Nowicki MO, Pierce AJ, Fishel R, Skorski T (2001) BCR/ABL regulates mammalian RecA homologs, resulting in drug resistance. Mol Cell 8: $795-806$

Steller MA, Zou Z, Schiller JT, Baserga R (1996) Transformation by human papillomavirus 16 E6 and E7: role of the insulin-like growth factor 1 receptor. Cancer Res. 56: 5087-5091

Valentinis B, Baserga R (2001) IGF-I receptor signaling in transformation and differentiation. Mol Pathol. 54: 133-137

vonWillebrand M, Zacksenhaus E, Cheng E, Glazer P, Ruth Buchdunger E, Cioffi CL, Law N, Stover D, Ohno-Jones S, Druker BJ, Lydon NB (1998) Abl protein-tyrosine kinase inhibitor STI571 inhibits in vitro signal transduction mediated by c-kit and platelet-derived growth factor receptors. J Pharmacol Exp Ther 295: 139-145

Wen B, Deutsch E, Marangoni E, Frasona V, Maggiorella L, Abdulkarim B, Chavaudra N, Bourhis J (2001) Tyrphostin AG1024 modulates radiosensitivity in human breast cancer cells. Br J Cancer 85: 2017-2021 